\title{
Integration in New Product Development: Case Study in a Large Brazilian High-Technology Company
}

\author{
Daniel Jugend', Sérgio Luis da Silva²
}

\begin{abstract}
Proficiency in management activities undertaken in product development processes is regarded as a key competitive advantage for companies, particularly for high-tech industrial firms, which benefit from the important competitiveness factor of launching products with a differentiated technological content. This paper's objective was to identify, through case study, practices for integration between the roles of R \& D with others involved in product development in a large Brazilian company of industrial automation. The results suggest some management practices to improve the integration in new products development, such as the use of employees from marketing with knowledge and experience previously gained from $R$ \& $D$ activities and uses the heavyweight product manager to solve synchronization problems between product and technology development.
\end{abstract}

Keywords: Integration; technology management; new product development; brazilian high-technology company.

\footnotetext{
' Department of Production Engineering - Universidade Estadual Paulista (Unesp).Av. Eng. Luiz Edmundo Carrijo Coube I4-0I, Bauru - SP Brazil.Telephone: 55 I4 31036I22 Email:daniel@feb.unesp.br

2 Department of Information Sciences - Federal University of Sao Carlos (UFSCar). Rod.Washington Luiz, km 235, I 3565 -905 - São Carlos SP - Brazil. Telephone 551633518374 Email: sergiol@ufscar.br
} 


\section{Introduction}

Proficiency in management activities undertaken in product development processes is regarded as a key competitive advantage for companies, particularly for hightech industrial firms, which benefit from the important competitiveness factor of launching products with a differentiated technological content (Haverila, 20I0).

Studies on production development management have emphasized the importance of integration between the product development process (PDP) and the activities of technological development, traditionally performed as a function of Research and Development (R \& D), as a good management practice associated with product development of high technological content (Drejer, 2002; Song and Song, 20I0; Brettel et al. 20II). This emphasis is due to the fact that the success of PDP also depends on the capacity and capability of companies to select, develop and transfer technologies gained in previous projects, to new ones. Examples include technical needs, technological development that translate into future products, anticipation of solutions and overlaps involved in the various phases of PDP.

The functional integration demanded by projects needing development and transference of technologies has additional complexities in relation to product development programs that do not demand technologically innovative efforts. This is because these projects also require the integration of $R$ \& $D$ activities and structures (i.e., for the identification, development, dominance and transference of technologies) combined with other roles of a company involved with PDP.

Integration between R\&D and PDP is defined as interactive and collaborative studies between different roles and company specialists with the purpose of creating knowledge and/or technological solutions that are transferrable to one or more products during the development of these products (Olson et al., 2001; Drejer, 2002; Nobelius, 2004). Notably, the technological innovation of products depends on work that combines knowledge belonging to various company roles and specialties (of a multi-tasking nature) with the intention of developing and launching a product that has a particular content involving new knowledge for commercial application. (Burgelman, Mandique and Wheelwright 200I; Brühl, Horsch and Osann, 2010; Brettel et al. 20II).
Some studies have indicated, however, that such integration is not a trivial activity (Griffin and Hauser, 1996; Park, Lim and Birnbaum-More, 2009; Brühl et al., 2010). Also observed by Griffin and Hauser (1996) and Song and Song (2010) was the presence of cultural barriers, communication difficulties, common understandings and different departmental objectives, which can be highlighted as aspects that tend to constrain the integration of different roles involved in the work of new product development within a company.

Despite the importance placed by various studies on the need for effective integration in the department of $R$ \& D with others involved in PDP, Drejer (2002), Kappel (200I) and Perks, Zhang and Kahn (2008) noted that many companies had significant difficulty in creating these integration procedures. Even their effective execution was considered by these authors as one of the biggest obstacles to good PDP management.

In a new product development, large technologically intensive companies deserve special attention because, unlike smaller businesses, they are better positioned to carry out technologically innovative systematic activities in PDP. In many cases, they have the necessary resources for this type of work, such as adequate installations, machinery and labour; investment in $R$ \& $D$ and specific skills in engineering, production, marketing and $R$ \& $D$.

For these reasons, the objective of this paper was present a compact review of the literature about integration between the roles of $R$ \& $D$ with others involved in product development, and a analysis of management practices conducive to the in a large Brazilian company of industrial automation.

Initially, this paper presents a bibliographic review of the subject. It then moves on to describe the research method employed, followed by a presentation of the company examined and the results achieved. 


\section{Bibliographic Review}

Projectsfornew products often depend on the development and transference of new technologies (Zapata and Cantú, 2008). Therefore, these projects require the collaborative and interactive work of various roles and skills (i.e., the need for integration between a company's R\&D and other functions involved with their PDP), for example, marketing, engineering, supply, production and logistics (Drejer, 2002; Song and Song, 2010). Table I, based on the work of Griffin and Hauser (1996) and Carvalho and Toledo (2008), generally illustrates the classical activities that various roles perform during product development programs containing technologically innovative roles.

\begin{tabular}{|c|c|}
\hline Role & General Activities \\
\hline M arketing & $\begin{array}{c}\text { Providing PDP with information on the market } \\
\text { (during pre-development, development and post- } \\
\text { development periods). }\end{array}$ \\
\hline Engineering & $\begin{array}{c}\text { Definitions on the product and process design, as } \\
\text { well as preparations for production. }\end{array}$ \\
\hline R \& D & $\begin{array}{c}\text { Identifying new technologies, developing and } \\
\text { dominating product and process design } \\
\text { technologies and preparing for the product. }\end{array}$ \\
\hline Supply & $\begin{array}{c}\text { Interacting with local suppliers regarding the } \\
\text { supply of raw materials, components and supply } \\
\text { development. }\end{array}$ \\
\hline Production & $\begin{array}{c}\text { Preparing prototype production and pilot } \\
\text { production; resolving problems so that the pilot } \\
\text { scheme may pass onto full-scale commercial } \\
\text { production; and performing actions needed to } \\
\text { improve process capabilities and cost reductions in } \\
\text { the product process. }\end{array}$ \\
\hline & \begin{tabular}{c} 
the \\
\hline
\end{tabular} \\
\hline
\end{tabular}

Table I. General activities and contributions of the different departments involved in product development process. 
Notably, as highlighted by Rozenfeld et al. (2006), although each of these roles experiences product development within its own perspective, its decisions and roles are complementary to one another. As such, they are related and should be carried out in conjunction and in an integrated manner, achieving the final purpose of product development and distribution that meets the company objectives.

The subject of integration has been studied by various business organisations for a number of decades. For Lawrence and Lorch (1973), this integration depended on existing collaboration between the different roles within the company. Upon interpreting what these authors had addressed on the subject of integration between the roles of R \& D and others involved in PDP (Drejer, 2002; Eldred and McGrath, 1997; lansiti,1998; Nobelius, 2004; Park, Lim and Birnbaum-More, 2009; Song and Song, 2010), we understood that this integration occurred when there was interactive and collaborative work between the different roles and skills, with the objective of creating technical knowledge and/or solutions that can be transferred to one or more products during PDP.

However, for Eldred and McGrath (1997) and Nobelius (2004), the work of integration is not a simple activity. Johansson et al. (2006) illustrated the complexity of integration by emphasising that the role of technology development needs to jointly operate with those roles that work with PDP, as they need to provide new ideas, materials, components and tools for such product development activities.

About the complexity of integration in development of new products, Song and Song (2010) identify important barriers to integration between $R$ \& $D$ and marketing, they are: physical separation, goal incongruity and cultural difference. Figure I, illustrates this concept and their impact on PDP performance.

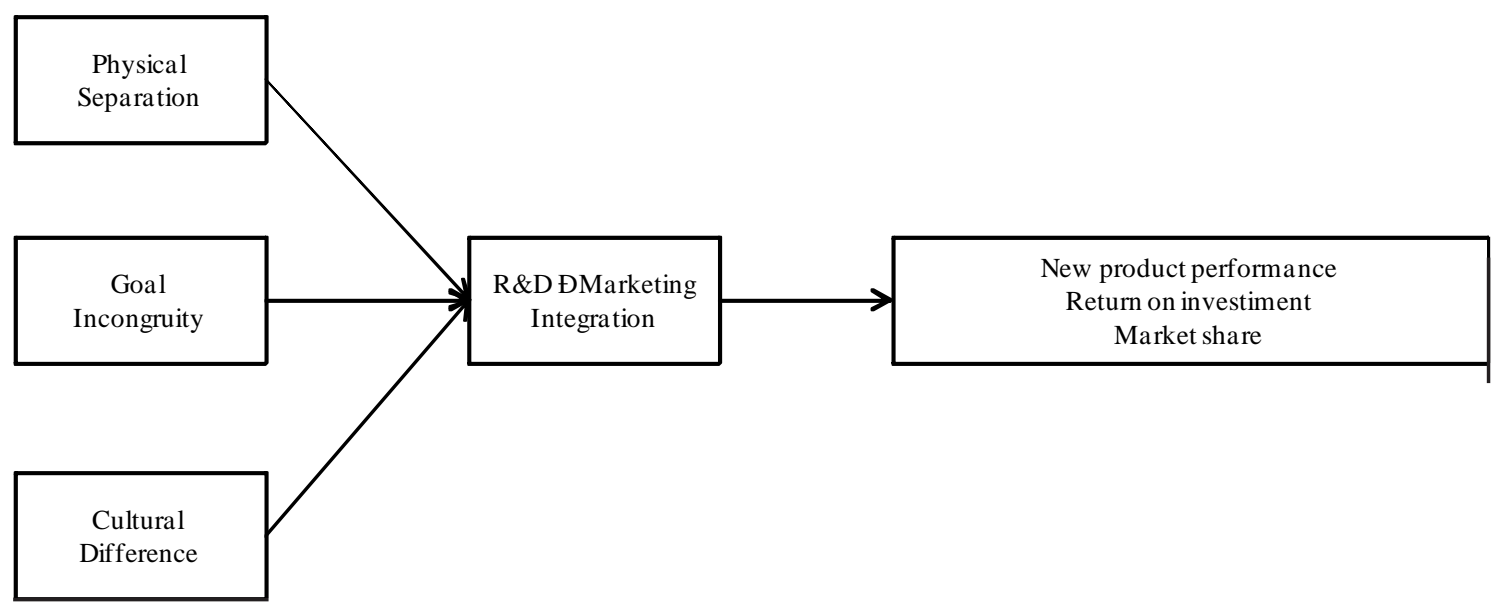

Figure I. Barriers between R\&D and marketing (source: adapted from Song and Song, 2010 p.386).

The work of Park, Lim and Birnbaum-More (2009) all highlighted the difficulties of enacting integration, mainly as a result of company growth and resulting increases in management complexity. Normally certain roles, such as marketing, engineering and $R \& D$, become very specialised regarding their different visions and goals. As such, they often act in isolation and with insufficient collaboration, communication or sharing of knowledge with the other departments. Griffin and Hauser (1996) and Maltz, Souder and Kumar (200I) observed that common problems associated with integration between these departments are derived from competition between engineering, marketing and R \& D.
After examining this issue from the perspective of the evolution of business organisations, Sim et al. (2007) stressed that the difficulty of integration between these roles is largely due to those influences resulting from scientific administration, which has long advocated that the division of product development roles into functions using a sequential approach is necessary for effective management.

To overcome the difficulty of such integration, recent revisions have shaped the relevant literature in the area of innovation and technology management dealing with the subject of product technology innovation and integration. The following studies were therefore selected: Pinto, 
Pinto and Prescott (1993), Calabrese (1997), Eldred and McGrath (1997), Katz and Allen (1997), Souder et al. (1997), Kim, Min and Cha (1999), Maltz, Souder and Kumar (200I) (200I), Koen et al. (2002), Leendres and Wirenga (2002), Eppinger and Chitkara (2006), LealEgaña, (2006), Rozenfeld et al. (2006), Brem and Voight
(2009), Gumusluoglu and Ilsev (2009), Love and Roper (2009), Park, Lim and Birnbaum-More (2009), Kelley and Lee (2010), Song and Song (2010) and Brettel et al. (20II). The proposed practices of these authors are presented in table 2. After, they are briefly described in the following paragraphs.

\begin{tabular}{|c|c|}
\hline Practices & Publication \\
\hline Cross-functional teams & $\begin{array}{l}\text { Pinto, Pinto and Prescott (1993); K atz and Allen } \\
\text { (1997); Calabrese, (1997); M altz, Souder and } \\
\text { K umar (2001); L eal-Egaa , (2006); L ove and } \\
\text { Roper (2009); Park, Lim and B irnbaum-M ore } \\
\text { (2009); Song and Song (2010). }\end{array}$ \\
\hline $\begin{array}{c}\text { Participation of } R \& D \text { personnel in market } \\
\text { research }\end{array}$ & $\begin{array}{l}\text { Roussel, Saad, B ohlin (1992); Souder, B uisson and } \\
\text { Garret. (1997); M altz, Souder and K umar (2001); } \\
\text { B rem and V oight (2009); B rettel et al. (2011). }\end{array}$ \\
\hline Physical proximity & $\begin{array}{c}\text { Pinto, Pinto and Prescott. (1993); L ee, Lee and } \\
\text { Souder (2000); M altz, Souder and K umar (2001); } \\
\text { K oen et al. (2002);, L eendres and W Wrenga (2002); } \\
\text { Eppinger and Chitkara (2006). }\end{array}$ \\
\hline $\begin{array}{l}\text { Project leaders with both technical and managerial } \\
\text { capabilities }\end{array}$ & $\begin{array}{l}\text { Eldred and M cG rath (1997); K im, M in and Cha } \\
\text { (1999); Toledo et al. (2008),;G umusluoglu and } \\
\text { Ilsev (2009); K elley and Lee (2010). }\end{array}$ \\
\hline
\end{tabular}

Table 2. Publications on integration of product development.

To minimise problems resulting from cultural barriers between departments involved in the product production process and related technologies, Maltz, Souder and Kumar (200I), Love and Roper (2009) and Park, Lim and BirnbaumMore (2009) proposed the use of cross-functional teams as a good managerial practice to increase the transference of knowledge and to achieve collaboration and interaction. By assembling teams and putting them face-to-face with different specialists involved with product development and technology, cross-functional teams can intensify the sharing of knowledge and information (Calabrese, 1997; Katz and Allen, 1997; Leal-Egaña, 2006; Song and Song, 2010). According to arguments presented by Calabrese (1997), in addition to improving functional integration, the presence of cross-functional teams facilitates sharing and provision of a vision for possible future problems and opportunities still in the phase of pre-development.
Souder, Buisson and Garret. (1997), Maltz, Souder and Kumar (200I) and Brettel et al. (20II) recognised that it was beneficial for managers from $R$ \& $D$ to participate in the activities of market research and to have contacts with clients along with personnel from marketing. According to Brem and Voight (2009), this practice permits personnel from $R$ \& $D$ to receive direct feedback from the market, therefore avoiding the translation of information according to the point of view of marketing. This practice has the potential, to bring together understandings of different specialists regarding client needs and characteristics, as well as possibilities for future products and technologies.

Pinto, Pinto and Prescott (1993), Maltz, Souder and Kumar (200I), Leendres and Wirenga (2002) and Eppinger and Chitkara (2006) noted that physical distance tends to inhibit integration between roles, which prejudices PDP 
performance. These same authors noted that as a result of face-to-face contacts, a greater degree of integration between the roles occurred when they worked in the same installations (i.e., physical proximity). It was also noted by Lee, Lee and Souder (2000) and Koen et al. (2002) that greater physical proximity tends to strengthen contacts and interactions between the different divisions and specialists involved in work demanding technical product innovation.

The project leader for new products needs to have various attributes such as the ability to motivate his members from different company areas to work in an integrated manner, the capacity to promote knowledge and information sharing between those members involved with the project and the skill to establish good contacts with the company's senior management (Kelley and Lee, 20l0). As such, this role is considered crucial for the successful integration of development projects involving high technological content. In addition, projects involving new products that depend on the development and transference of new technologies tend to encounter greater difficulties because the work of the project leader also extends to R \& D (Kim, Min and Cha, 1999).

In agreement with such observations, studies by Eldred and McGrath (1997), Kim, Min and Cha. (1999) and Gumusluoglu and Ilsev (2009) also highlighted the fact that project leaders with both technical and managerial capabilities could enhance integration. These authors noted that leaders with this sort of profile normally provided managerial clarity to their technical roles while simultaneously bringing technical necessities and possibilities to these managerial roles. This can be beneficial for common understanding and, at a minimum, a basic consensus between different divisions and specialists involved in the development work.

Having presented a theoretical review on integration, in particular involving the summaries of the four practices between R \& D and other personnel involved in PDP, we will next explore and discuss the research methodologies employed in our study.

\section{Research Methodology}

With the objective of identifying those practices adopted for integration among different divisions and specialties involved in R \& D and PDP within a technological base company, it was decided to use a qualitative research approach. This decision was made because, in addition to the difficulty associated with measuring specific variables, it was necessary to understand the opinions regarding these variables. Therefore, following the recommendations of Bryman (2006), the presence of a researcher in the field was indispensable.

According to Yin (2005), it is appropriate when the researcher of a case study requires a greater understanding of the facts being researched. Moreover, Yin (2005) states that a case study allows for a deeper analysis of a number of relatively small situations, as it provides emphasis to a wider understanding of the phenomenon in question.

This is an important case study, because the company researched is the largest Brazilian company of industrial automation. In addition the company was the possession of systemic development and technology transference activities for their new product programs and a demonstration of expenditure about $10 \%$ of their total invoices focused on innovative activities. By comparing this expenditure with the results of the Innovative Technology Industrial Research - PINTEC-2008 carried out by the Brazilian Institute of Geography and Statistics (IBGE), which was based on the Oslo Manual, it was possible to confirm that company researched to see whether they fit into the Brazilian scenario in terms of innovative effort.

To define large sized companies, SEBRAE (Brazilian Support Services to Small and Micro Companies) and IBGE criteria were used. According to these entities, large companies classified as those with above 500 employees.

Semi-structured interviews were carried out following a research road-map containing both open and closed questions. Following the recommendation to carry out case study, the company was visited, and different specialists involved in R \& D - PDP integration were interviewed, including directors; engineers; and managers and coordinators from R \& D, and marketing (Gibbert and Ruigrof, 20l0). 


\section{The Case Study}

With the aim of presenting the results of the case studies, initially profiled that company that was researched. Later, the integration practices displayed were demonstrated and analysed.

\section{I Characterization of the Company}

The company is large and operates in the industrial automation; it has twelve units the region of Ribeirão Preto (SP, Brazil) and a production unit in the USA. The firm has approximately nine hundred employees, of these; one hundred and forty are allocated to R\&D and engineering activities.

It started its activities in 1974 developing and manufacturing products for products for industrial automation serving the sugarcane sector, this was due to the needs of industries where the company is located. Nowadays also serves the sectors of oil and gas. About 30\% of its sales are to foreign markets (mainly U.S.A., China and Middle Eastern countries).

The platforms of products that are marketed by the company including, programmable logic controller (PLCs) and transmitters (pressure, temperatureand density), many of these products incorporate the following technologies: electronics, software and precision mechanics.

Technology development was considered by the company as a specific step in the process of product development (PDP), while developing knowledge was observed as necessary for the application of technologies to products and other specific process. That company did not possess strategies that guided plans. Nor did have programs with the intention of strengthening or expanding their future technological capabilities, without having an immediate commercial goal in mind and without a good identity regarding the specific product.

In accordance with Table I and from our literature review, it was possible to establish a relationship between engineering job descriptions with those roles defined in the product project, process project and product preparation, as well as with those roles involved with $R \& D$, such as identification, development and technology domination. However, this phenomenon of functional roles divided between engineering and $R$ \& $D$ was not observed within the company that was researched. It was noted that the company adopted the same function, referred to as R \& $D$, for both types of the above mentioned tasks.

However, possessed a well-structured marketing and production division, which, in accordance with the literature reviews, were respectively responsible for providing PDP information regarding the market as well as knowledge needed for the implementation and control aspects related to production processes.

\subsection{Integration Practices in the Company}

Based on those management practices for integration between the roles of $R$ \& $D$ and those other functions involved with PDP, briefly discussed in the theoretical part of this paper, the effective practices adopted by the researched company is presented below for analysis. Initially, analysis how the company organize their crossfunctional teams.

The company has institutional policies in the adoption of cross-functional teams. This is adopted at all stages of technological and product development. They count on representatives from $R$ \& $D$, production, supply and marketing. These teams work throughout the product technology development. The production function of company has a team of coordinators who work during the morning period in the building where the $R$ \& $D$ function is installed and during the afternoon in the company factories. This was suggested by the company as a practice which would strengthen the meetings between representatives of these two functions ( $R$ \& $D$ and Production), in order to help the transmission and sharing of information and knowledge between them.

The presence of cross-functional teams is stronger at the strategic planning and pre-development stages. Normally they would form themselves into groups with representatives from R \& D, manufacturing, marketing and supplies to evaluate and approve development projects for new products and technologies. However, after deliberations regarding the products and technologies to be developed, the rest of the work was led by the representatives from R \& D.

These results are in line with research by Olson et al. (200l), who verified that the integration between representatives from technical functions and management departments occurred normally in an intense manner du- 
ring pre-development stages. After all, these are decisionmaking moments for products and technologies about to be developed, which requires the need for client information and constraints, as well as technological possibilities before commencing on actual development work. This fact alone justifies the presence of representatives from marketing and $R$ \& D in these teams at the time of pre-development.

Frequent failures in its forecasts and operational problems during its technological development projects, which were transferred to one or more products during PDP. Whenever this occurred, it was company practice to form an organisational structure called the "Task Force Team" led by a director from that area (a "heavyweight" individual), to accelerate the work and try to fulfil the developmental activities within the scheduled timeframe.

Regarding the participation of $R$ \& $D$ personnel in market research, it was noted that unlike the recommendations from the researched literature (Souder, Buisson and Garret, 1997; Maltz, Souder and Kumar, 200I; Brettel et al., 20II), the company had no adopted this practice. It was noted that the exclusive attributes of the marketing role and the employees who "work in the field" (e.g., installations and technical assistance) consisted of the acquisition of information regarding client needs. Specifically, the company did not employ specialists who operated in roles specifically related to the definition of the product and the overall process (in addition to the identification, development and domination of new technologies) for working together with those marketing activities related to client contact and market research.

Although there is a constant necessity to translate the market needs obtained by marketing into technical development work that can be carried out by $R \& D$, the respondents of the interviews did not highlight this fact as a problem in integration. Those employees working in marketing were normally aware of the technical aspects of the products as well as the relative technologies that were involved, which tended to foster a mutual understanding between the necessities and possibilities regarding the work of both technical and managerial personnel involved in the development work. It was indicated that the acquisition of this technical knowledge should involve, above all things, the practice of knowledge accumulation in their marketing departments, especially by those employees who are qualified (e.g., graduates or those who completed technical courses) or those who have had previous work experience in technical functions.
The physical proximity of departments consists of another practice recommended for improving interaction and consequently integration. In the company $R$ \& D, marketing and manufacturing operate in separate installations. There was a similarity between the observations noted from relevant literature and that of the company, on the fact that physical distance effectively establishes itself as a constraining element for the interaction and consequently the integration in the development of products (Maltz, Souder and Kumar, 200I; Leendres and Wirenga, 2002). The unsuitability by virtue of geographic distance between the roles was further emphasized in a statement from the director of $R$ \& $D$, who stated:

"When I need to talk to a certain employee in Marketing, I have to telephone and request a meeting. I do not always manage to arrange this. However, when I need to talk with some coordinator from the R \& D area, all I have to do is to go to his desk".

Revision of relevant literature also indicated that having leaders who were jointly qualified in both technical and managerial areas was considered to be good managerial practice for integration. In the company the project leaders possessed technical qualifications (all had graduated in engineering). It was noted that the managerial experience of the project leaders from company is resulted from that managerial experience gained from past projects and not through formal education in the area of management. Similarly, Brazilian research into this topic, such as the study by Toledo et al. (2008), observed that lacking managerial qualifications, as was the case for the projects in company, had constrained interactions between marketing with $R$ \& $D$. That due to their exclusive technical profiles, their leaders had difficulties with communicating in an efficient manner and sharing knowledge with representatives from marketing. These also indicated that this situation involving their leaders normally prejudiced the performance of PDP.

The technological development projects carried out achieved new results because their leaders called for meetings with the managers of other technological product development projects under progress. The purpose of these meetings was to share knowledge that had been acquired from these projects with other teams, as well as to study the immediate possibilities of applying technologies that were being developed in other new projects. This practice was mostly beneficial for integration efforts because, apart 
from generating improvements in analysing the possibilities for the application of technologies developed in other new projects, it also intensified the sharing of acquired knowledge from the technological development work by $R$ \& $D$ with knowledge from other parties.

\section{Final Considerations}

This work contributes to presenting a set of practices for the management of product development project integration involving technological innovation. With the objective of improving the integration of new product development, It was observed, for example, that apart from the traditional use of cross-functional teams, the company adopted practices such as the use of employees from marketing with knowledge and experience previously gained from R \& D activities, and the "Task Force Team" to accelerate the work and try to fulfil the developmental activities within the scheduled timeframe.

Unlike the findings stated in other publications (Maltz, Souder and Kumar, 200I; Brettel et al., 20II), the company not involving their R \& D personnel in market research activities showed concerns in combining their marketing roles with those of their technical departments (e.g., engineers who had previous experience in $R \& D$ ). By facilitating the translation of market needs data for the technical work as well as requirements for technological product development, this practice demonstrated benefits to the integration of both technical and managerial roles involved with development work.

Daily allocations of production teams to the $R$ \& $D$ department intensified the integration process between these two functions by strengthening the face-to-face meetings between the specialists through geographical proximity. It was understood that a similar practice could also be applied by combining the marketing teams with the $R$ \& $D$ department.

The application of the practices identified in this study can provide help in uniting different specialist roles, which frequently face differing visions and challenges in obtaining a common understanding regarding the development of technical products. These difficulties tend to hamper various activities related to the new product development such as the translation of a client's technical product needs, which can consequently prejudice the development of those products and associated technological innovations.
As it's a large Brazilian company of industrial automation, was expected to present with significant difficulties regarding the integration of those roles involved technological development activities and those involved in PDP. However, this theory was not confirmed. It is possible that the adoption of a set of managerial practices favoured integration, as a result of the consolidation of cross-functional teams and the daily allocation of coordinators from the production function. These members worked together on the development side by contributing to reductions in expected problems related to the integration between product development.

In reviewing this case study, it was noted that the company had a competitive differentiator within their organisational structures that focused on technical development activities. It was also observed that the company that integrated similarities across those activities typically associated them to engineering and $R$ \& $D$ divisions. This type of structure resulted in greater agility in terms of product development, which can provide a competitive advantage against the competition. However, it is necessary to recognise that unlike many large-sized and/or multinational companies with a technological base, the companies in this study had $R$ \& D centres exclusively dedicated to the activities of identifying, developing and dominating technologies in general. The company that was researched expended their $R$ \& $D$ resources with the objective of developing future technologies, unless they had an immediate commercial interest associated with the particular product in question.

These different objectives and operational procedures related to technological development are factors that can motivate the adoption of divergent organisational structures between those companies, which were the object of this research study. This is in comparison to characteristics common in larger and/or multinational companies with a technological base, which often have formal R \& D centres.

It is important to stress that this exploratory and qualitative study sought to familiarise itself with those concepts surrounding the integration of $R$ \& $D$ and PDP in a large Brazilian technology-based company and this managerial practices conducive to achieving this integration. The empirical results of this study, however, should be viewed with a certain amount of methodical restraint. Given the limitations of the methods employed, one must take into 
consideration that the included companies emphasised their innovative product technology activities. Therefore, their results should not be generalised for all technologybased medium and large companies.

Another limitation of this research was its exclusive focus on organisational elements used to investigate the phenomena of integration. It is known, however, that apart from the focus on technological information, there are other managerial methods such as, technology roadmap, stage-gates and value engineering, all of which are recognised methods for stimulating integration between different specialists and functions involved with product technology development. Future studies on technology management and new product development should investigate the subject of integration from the viewpoint of these abovementioned methods.

\section{References}

BREM, A., Voight, K. (2009). Integration of market pull and technology push in the corporate front end and innovation management - insights from the Germany software industry, Technovation, 29 (5), 35I-367.

BRETTEL, M., Heinemann, F., Engelen, A., Neubauer, S. (20II). Cross-functional integration of R\&D, Marketing and Manufacturing in radical and incremental product innovations and its effects on project effectiveness and efficiency, The Journal of Product Innovation Management, 28 (2), 25I-269.

BRÜHL, R., Horsch, N., Osann, M. (2010). Improving integration capabilities with management control, European Journal of Innovation Management, I3 (4), 385-408.

BURGELMAN, R. A., Mandique, M. A., Wheelwright, S. C. (200I). Strategic Management of Technology and Innovation, $3^{a}$ ed., McGraw-Hill Book, Singapure.

BRYMAN, A. (2006). Integrating quantitative and qualitative research: how is it done? Qualitative Research, 06 (I), 97-II3.

CALABRESE, G. (1997). Communication and co-operation in product development: a case study of European car producer, R\&D Management, 27 (3), 239-252.
CARVALHO, J. L. M. and Toledo, J. C. (2008). The challenge of integrating applied research and product development process: case study, Product: Management \& Development, 06(2), I73-I8I.

DREJER, A. (2002). Integrating product and technology development. International Journal Technology Management, 24 (2/3), I24-I42.

ELDRED, E. W., McGrath, M. E. (1997). Commercializing new technologies - II, Research Technology Management, 40 (2), 29-33.

EPPRINGER, S. D., Chitkara, A. R. (2006). The practice of global product development, MIT Sloan Management Review, 27 (4), I-II.

GIBBERT, M., Ruigrok, W. (20I0). The "what" and "how" of case study rigor: three strategies based on published work, Organizational Research Methods, 14 (4), 7I0-737.

GRIFFIN, A., Hauser, J. R. (1996). Integrating R\&D and marketing: a review and analysis of the literature, Journal of Product Innovation Management, 13(3), 191-215.

GUMUSLUOGLU, L., Ilsev, A. (2009). Transformational leadership and organizational innovation: the roles of internal and external support for innovation, The Journal of Product Innovation Management, 26(3), 264- 277.

HAVERILA, M. (20I0). The marketplace variables in successful and unsuccessful NPD projects in technology intensive companies. Journal of Technology Management \& Innovation, 5(3), |2I-I36.

IANSITI, M. (1998). Technology integration: making critical choices in a dynamic world, HBS Press, Boston.

JOHANSSON, G., Magnusson, T., Säfsten, K., Lakemond, N. (2006). Case studies on the application industrial innovation process, in: Second European Conference on Management of Technology - Euromot, Birmingham, United Kingdom.

KAPPEL, T. A. (200I). Perspectives on roadmaps: how organisations talk about the future. The Journal of Product Innovation Management, 18 (I), 39-50. 
KATZ, R., Allen, T. J. (1997). Organizational issues in the introduction of new technologies. In: Katz, R. (Ed.), The human side of managing technological innovation. Oxford University Press: Oxford, 384-410.

KELLEY, D., Lee, H. (2010). Managing innovation champions: the impact of Project characteristics on direct manager role, Journal of Product Innovation Management, 27 (7), 1007-1019.

KIM, Y., Min, B., Cha, J. (1999). The roles of R\&D team leaders in Korea: a contingent approach, R\&D Management, 29 (2), 153-165.

KOEN, P. A., Ajamian, G. M., Boyce, S., Clamen, A., Fisher, E., Fountoulakis, S., Johnson, A., Purl, P., Seibert, R. (2002). Fuzzy front end: effective methods, tools, and techniques, In: Bellivean, P.; Griffin, A. and Somermeyer, S. (edts), The PDMA Handbook of new product development. John Wiley \& Sons, New Jersey, I-35.

LAWRENCE, P., R., Lorsch, J. W. (1973). As empresas e o ambiente: diferenciação e integração administrativas, Vozes, Petrópolis.

LEAL-EGAÑA, A. (2006). Multidisciplinary teams: the next step in the science. Journal of Technology Management \& Innovation, I(I), 2I-26.

LEENDERS, M. A. A. M., Wierenga, B. (2002). The effectiveness of different mechanisms for integrating marketing and R\&D, The Journal of Product Innovation Management, 19 (2), pp. 305-317.

LEE, J.; Lee, J., Souder, W. E. ( 2000). Differences of organizational characteristics in new product development: cross-cultural comparison of Korea and US, Technovation, 20 (9), pp.497-508.

LOVE, J. H., Roper, S. (2009). Organization innovation: complementarities between cross-functional teams, Technovation, 29 (3), 192-203.

MALTZ, E., Souder, W., E., Kumar, A. A. (200I). Influencing $R \& D / m a r k e t i n g$ integration and the use of market information by R\&D managers intended and unintended effects of managerial actions, Journal of Business Research, 52 (I), 69-82.
NOBELIUS, D. (2004). Linking product development to applied research: transfer experiences from an automotive company, Technovation, 24 (4), 32I-334.

OLSON, E. M., Orville, C. W., Ruekert, R. W., Bonner, J. B. (200I). Patterns of cooperation during new product development among marketing, operations and R\&D: implications for project performance, Journal of Product Innovation Management, I8 (4), 258-27I.

PARK, M. H., Lim, J. W., Birnbaum-More, P. H. (2009). The effect of multiknowledge individuals on performance in cross-functional new product development teams, The Journal of Product Innovation Management, 26 (I), 89-96.

PERKS, H., Zhang, C., Kahn, K. (2008). An empirical evaluation of the effect and nature of R\&D - Marketing integration in new product development in incumbent Chinese firms, in: I5TH International Product Development Management Conference-IPDM, Hamburgo, Germany.

PINTO, M. B., Pinto, J. K., Prescott, J. E. (1993). Antecedents and consequences of project team cross-functional cooperation, Management Science, 39 (10), 128I-1297.

ROUSSEL, P. A.; Saad, K. N.; Bohlin, N. (1992). Pesquisa \& Desenvolvimento: como integrar P\&D ao plano estratégico e operacional das empresas como fator de produtividade e competitividade. São Paulo: Makron Books.

ROZENFELD, H., Forcellini, F. A., Amaral, D. C., Toledo, J. C., Silva, S. L., Alliprandini, D. H., Scalice, R. K. (2006). Gestão de desenvolvimento de produto: uma referência para a melhoria do processo, Saraiva, São Paulo.

SIM, E. W., Griffin, A., Price, R., Vojak, B. (2007). Exploring differences between inventors, champions, implementers and serial innovators in developing new products in large, mature firms. Creativity and Innovation Management. 6 (4),422-435.

SONG, L. Z., Song, M. (2010). The role of information technologies in enhancing R\&D-Marketing integration: an empirical investigation, Journal of Product Innovation Management, 27( 3), 382-40I. 
SOUDER, W. E., Buisson, D.,Garret, T. (1997). Success through customer-driven new product development: a comparison of US and New Zealand small entrepreneurial high technology firms, Journal of Product Innovation Management, 14 (6), 459-472.

TOLEDO, J. C., Silva, S. L., Mendes, G. H. S., Jugend, D. (2008). Fatores críticos de sucesso no gerenciamento de projetos de desenvolvimento de produto em empresas de base tecnológica de pequeno e médio porte, Gestão \& Produção, 15 (I), II7-I34.

YIN, R. K. (2005). Estudo de caso: planejamentos e métodos, $3^{\text {a }}$ ed., Bookman, Porto Alegre.

ZAPATA, A. R. P., Cantú, S. O. (2008). Gestion estratégica de la tecnologia em el predesarrolo de nuevos productos. Journal of Technology Management \& Innovation, $3(3), 112-122$. 